\title{
Azepanodipterocarpol is potential candidate for inhibits influenza H1N1 type among other lupane, oleanane, and dammarane A-ring amino-triterpenoids
}

\author{
Irina Smirnova $\mathbb{1}^{1} \cdot$ Anastasiya Petrova ${ }^{1}$ Alexander Lobov ${ }^{1} \cdot$ El'za Minnibaeva $^{2} \cdot$ Thao Tran Thi Phoung ${ }^{3}$. \\ Loc Tran Van $^{3} \cdot$ Myint Myint Khine ${ }^{4} \cdot$ Iana Esaulkova ${ }^{5} \cdot$ Alexander Slita $^{5} \cdot$ Vladimir Zarubaev $^{5} \cdot$ Oxana Kazakova $^{1}$
}

Received: 2 November 2021 / Revised: 28 January 2022 / Accepted: 30 January 2022 / Published online: 4 March 2022

(c) The Author(s), under exclusive licence to the Japan Antibiotics Research Association 2022

\begin{abstract}
A series of lupane-, oleanane- and dammarane-based triterpenoids with 3 $\beta$-amino, A-ring azepano- and 3,4-seco-fragments has been synthesized and evaluated for antiviral activity against influenza $A(H 1 N 1)$ virus. It was found that azepanodipterocarpol $\mathbf{8}$ and 3 3 -amino-28-oxoallobetulin $\mathbf{1 1}$ showed antiviral activity with $\mathrm{IC}_{50} 1.1$ and $2.6 \mu \mathrm{g} \mathrm{ml}{ }^{-1}$, and selectivity index of 19 and 10 , respectively.
\end{abstract}

\section{Introduction}

Viruses are the most common intracellular pathogens that cause deadly infectious diseases and surround us everywhere in wildlife. Every year, with enviable regularity, humanity is faced with great and little-known danger, threatening all of us with epidemics and the death of a large number of people. According to a 2018 report by the World Health Organization, over 37.6 million people are

Supplementary information The online version contains supplementary material available at https://doi.org/10.1038/s41429022-00514-w.

Irina Smirnova

si8081@yandex.ru

1 Ufa Institute of Chemistry, Ufa Federal Research Center, Russian Academy of Sciences, 71 pr. Oktyabrya, 450054 Ufa, Russian Federation

2 Department of Technical Chemistry and Materials Science, Bashkir State University, Faculty of Engineering, 32 Zaki Validi, 450076 Ufa, Russian Federation

3 Institute of Chemistry - Vietnamese Academy of Science and Technology 18, Hoang Quoc Viet street 18 Cau Giay district, Hanoi, Vietnam

4 Department of Chemistry, University of Yangon, University Avenue Road, Kamayut Township, 11041 Yangon, Myanmar

5 Department of virology, St. Petersburg Pasteur Institute of Epidemiology and Microbiology, Experimental virology laboratory, 14 Mira St., St. Petersburg 197001, Russian Federation infected with the human immunodeficiency virus (HIV) and to date, this virus has claimed more than 32 million lives [https://www.who.int/ru/news-room/fact-sheets/deta il/hiv-aids]. People are constantly threatened by many other and emerging viruses that cause the highly pathogenic avian influenza virus, influenza A subtype (H5N1 [1] and H7N9 [2]), severe acute respiratory syndrome coronavirus [3], the Ebola virus [4], the Middle East respiratory coronavirus syndrome [5]. Today the ranks of these economically and socially dangerous infections have been replenished with another one - COVID-19, with more than 4.5 million deaths registered worldwide [https://apps.who.int/iris/bitstream/handle/10665/331685/ nCoVsitrep01Apr2020-eng.pdf]. Respiratory infections are of global importance, and the last two years have shown the particular importance of research work aimed at finding effective antiviral drugs, since the emergence of new viruses [3-5] and drug-resistant virus strains [6] has been a continuous process, leading to outbreaks and pandemics. A particularly high mutation rate is observed in viruses that cause severe acute respiratory syndrome, including all types of influenza viruses [7, 8], and coronaviruses $[3,5]$.

Influenza causes annual epidemics that quickly spread from country to country, involving in severe cases (pandemics) a significant part of the world's human population [9]. Despite the advances made in the field of chemotherapy, vaccination, and immunology of influenza, it remains a difficult-to-control infection due to high genetic variability and various long-term complications after the acute stage, 
leading to "latent" or secondary mortality caused not by the influenza virus itself, but by virus-induced secondary processes [10]. The rapid development of resistant variants of influenza reduces the effectiveness of the anti-influenza properties of active substances; therefore, the search for new compounds with antiviral properties is an extremely important objective of high priority.

Chemical compounds isolated from plants are widely used in many different areas of activities that are successfully used in pharmacotherapy [11]. The flora land is rich in medicinal herbs and plants, which contain biologically active components providing the main pharmacological action. A significant part (about 24.4\%) of these metabolite compounds are triterpenes [12]. Among them, tetracyclic and pentacyclic triterpenes as well as their semisynthetic derivatives possesses a wide spectrum of biological activity, including antitumor, antimicrobial, antiparasitic, antibacterial, antiinflammatory, and hepatoprotection action [13, 14].

The antiviral activity of this class of compounds also has a fairly wide spectrum. Triterpenes are active against viruses such as human immunodeficiency viruses, hepatitis B and C, various types of influenza viruses, acute respiratory viral infections, herpes viruses, human enterovirus, Epstein-Barr, and Zika viruses [15, 16]. The potential of triterpenoids as antiviral platforms is very promising. This is evidenced by such good examples as bevirimat - an anti-HIV drug derived from a betulinic acid [17], glycyrrhizinic acid-a native platform used for the treatment of chronic hepatitis [18]. Recently, 3-O- $\beta$-chacotriosyl oleanolic acid benzyl ester has been identified as a novel low molecular weight inhibitor of the SARS-CoV-2 virus [19]. Therefore, research in this area is very actual and should be extensively continued.

All of the above, in particular the ability of the virus to develop resistance to antiviral drugs, indicates the need to search and develop effective and cheap anti-influenza agents with a wider spectrum of action based on plant metabolites and their semisynthetic derivatives. Since often, the activity of chemically modified compounds is not inferior to and sometimes exceeds the activity of native compounds [20].

In this context, in a continuation of our research in the field of antiviral properties of semisynthetic triterpene derivatives [21-24], a synthesis and an antiviral activity screening of a series of lupane, oleanane, and dammarane types amino-triterpenoids against the H1N1 influenza virus have been performed.

\section{Results and discussion}

The literature data showed that nitrogen-containing derivatives of triterpenoids in A-ring led to an increase of antiviral activity, in particular, anti-influenza activity [25]. These results include mostly oxime and amide functions at $\mathrm{C} 3$ or
C28 positions. For example, 3-oxime of betulonic acid and $L$-leucine-28-amide demonstrated $90 \%$ suppression of influenza virus A H7N1 (EC EC $_{50}$ 2.17, MTT/EC E $\left._{50} 392.16\right)$ $[26,27] 3 \beta$ - and $3 \alpha$-amino-derivatives of oleanolic acid possessed inhibitory activity on HCV protease [28].

Alnincanone having a framework of dammarane, echinocystic acid-lupane type triterpenoid, and methyl ester of ursolic acid possess pronounced inhibiting activity against influenza type A virus (protection index 60\%) and high antiviral activity against influenza type B (protection index $80 \%$ ) [29]. 3-Cyanoethoxy derivatives of dammarane triterpenoids alnincanone and dipterocarpol, 3-tetrazolyl derivative of dammarolide had a considerable activity with SI 10, 9, and 26 against influenza virus A/Puerto Rico/8/34 (H1N1) [30].

The presence of the seven-membered azepane fragment in cycle $\mathrm{A}$ in various types of triterpenoids leads to an increased native and occurrence of new types of biological activity. Azepanotriterpenoids are the promising compounds toward $M$. tuberculosis [31], ESCAPE pathogens [32, 33], and HSV-1 [33].

Taking in mind that to combine amino-function with the seco fragment in the A cycle of triterpenoids is also an effective direction in the search for antiviral platforms we have shown that lupane 3,4-seco-3,28-bis- $N, N$-methylpiperazine-amide has $\mathrm{IC}_{50} 27 \mu \mathrm{M}$ and SI 7.1 against Flu A H1N1 strain [34]. A lupane 2,3-seco aldehydoacid, diacid, 3-aldoxime derivatives can suppress the reproduction of HSV-1 and Flu A (EC 50 from 0.06 to $21.3 \mu \mathrm{M}$ ) [35, 36]. Ethyl $\beta$-alaninate diamide 2,3 seco-lupane was shown to combine antiherpetic $\left(\mathrm{EC}_{50} 4.1 \mu \mathrm{M}\right)$ and anti-HIV activity $\left(\mathrm{EC}_{50} 5.1 \mu \mathrm{M}\right)$ [37] and $\mathrm{C}-28$ amide conjugate with a 2aminpropane-1,3-diol was the most active compound against herpes simplex virus type I $\left(5.7 \mu \mathrm{M}, \mathrm{MTC} \mathrm{EC}_{50}\right.$ 32.2) [38]. Inhibition of the serotype A viruses with a protection index of $60 \%$ by 2,3- and 3,4-seco-dammarane acids was reported in [39].

Based on our previous reports on the antiviral activity of nitrogen-containing triterpenoids [21-24, 34, 40] and considering the pronounced anti-influenza activity of lupane, oleanane, and dammarane triterpenoids in this work we focused our attention on a synthesis of a series of this type triterpenoids with $3 \beta$-amino, A-ring azepano- and 3,4-seco3 -amino-fragments and their evaluation against influenza H1N1 type. Need to note that semisynthetic dammarane triterpenoids have been a few studied against influenza viruses and search for new antiviral platforms based on this type of triterpenoids are a relevant direction.

\section{Chemistry}

As was mentioned above, the triterpenes and their nitrogen derivatives demonstrated activity against different strains of the influenza virus. 


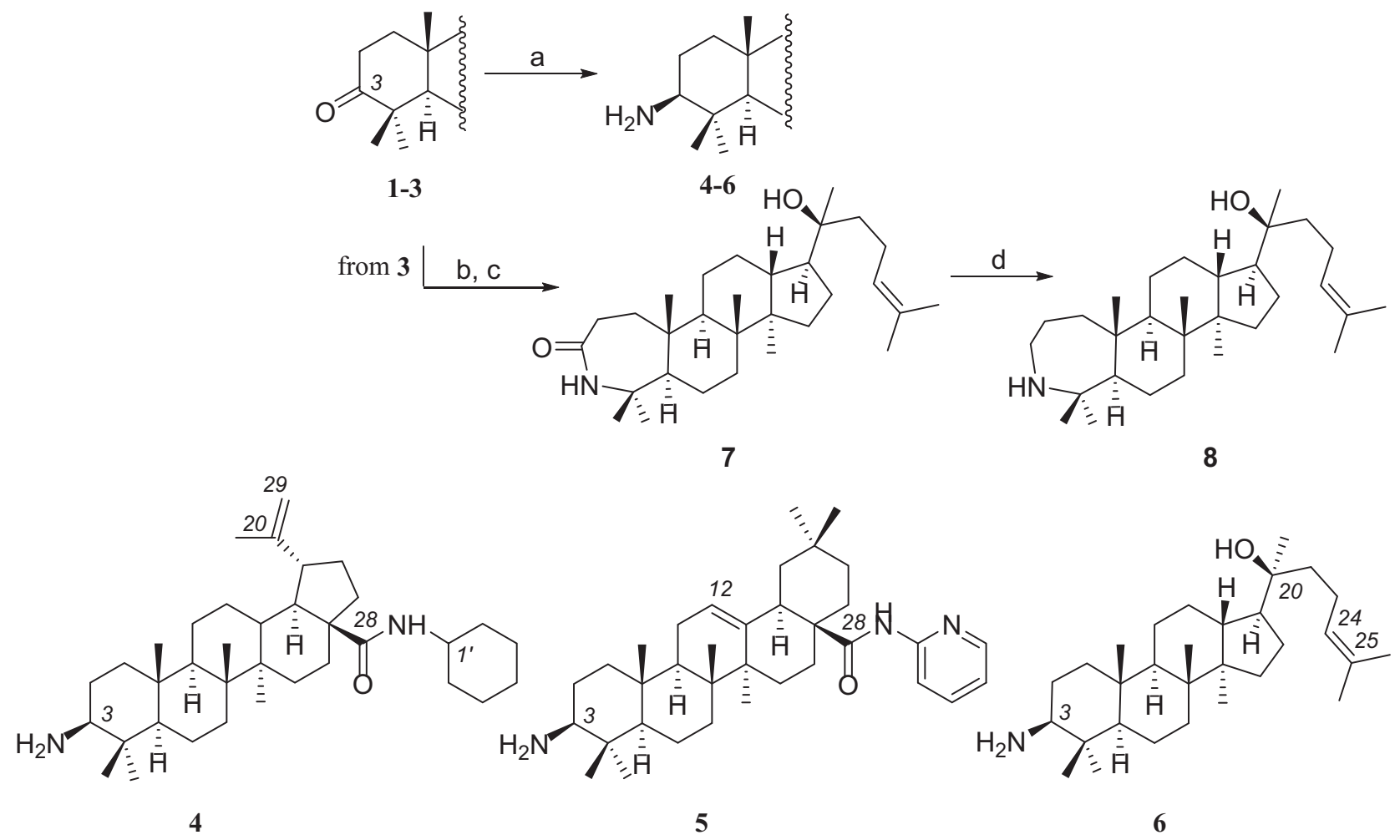

Scheme 1 Synthesis compounds 4-8: a. $\mathrm{CH}_{3} \mathrm{COONH}_{4}, \mathrm{NaBH}_{3} \mathrm{CN}, \mathrm{CH}_{3} \mathrm{OH}, 22{ }^{\circ} \mathrm{C}, 12 \mathrm{~h}$; b. $\mathrm{NH}_{2} \mathrm{OH} \mathrm{HCl}, \mathrm{Py}$, reflux; c. SOCl 2 , dioxane, $22{ }^{\circ} \mathrm{C}$, $30 \mathrm{~min}$; d. $\mathrm{LiAlH}_{4}$, THF, reflux, $3 \mathrm{~h}$. The parent compounds were described in 1 [41], 2 [42], dipterocarpol 3 [43]

The three series of A-ring nitrogen-containing derivatives with 3 $\beta$-amino, azepano- and 3-amino-3,4-seco-fragments have been designed and synthesized. These compounds are presented by new 4-6, and $\mathbf{8}$ (Scheme 1) and previously synthesized 9-19 (Fig. 1) triterpenoids.

Reduction amination was applied to prepare compounds with a free amino group at $\mathrm{C} 3$. The reaction of 3-oxoderivatives betulonic acid cyclohexylamide 1 [41], oleanonic 2-aminopyridine-amide 2 [42] and dipterocarpol 3 [43] with ammonium acetate in presence of $\mathrm{NaBH}_{3} \mathrm{CN}$ in methanol at room temperature lead to compounds 4-6 with yields of $82-89 \%$ after purification by column chromatography. Early compound $\mathbf{6}$ was isolated from a plant Astragalus genus [44]. The structures of compounds 4-6 were confirmed by spectroscopic methods (see Supplementary material S1-S9). In the ${ }^{13} \mathrm{C}$ NMR spectra, the signals of the $\mathrm{C} 3$ carbon atom at the amino group were detected at $\delta_{C}$ 56.60-59.74 ppm, in the ${ }^{1} \mathrm{H}$ NMR spectra $\mathrm{H}_{\alpha}-3$ proton signals resonated at $\delta_{H} 2.20-2.72 \mathrm{ppm}$ as a doublet of doublets.

The presence of $\mathrm{NH}_{2}$-group at $\mathrm{C} 3$ position of compound 6 is confirmed by cross peaks of nearby protons $\left(\mathrm{H}_{\mathrm{eq}}-2, \mathrm{H}-\right.$ $3)$ in the $\left\{{ }^{1} \mathrm{H},{ }^{15} \mathrm{~N}\right\} \mathrm{HMBC}$ spectrum with amino-nitrogen at $\delta_{N} \sim 31 \mathrm{ppm}$ (Fig. 2). The stereochemistry of the chiral center at C3 was established using analysis of NOESY spectra and coupling constants of compound 6. Signal splitting of H-3 $\left(\delta_{H} 2.34 \mathrm{ppm}\right)$ with coupling constants of 11.8 and $4.1 \mathrm{~Hz}$ indicates its axial position. The key signals for the configuration assignment are NOESY cross-peaks $\mathrm{H}-3$ with $\mathrm{H}-5$ and $\mathrm{H}_{\mathrm{ax}}-1$ protons which are indicative of both axial alignment of the proton at C-3 and its $\alpha$-configuration, which is confirmed the data [45].

The treatment of dipterocarpol 3 with $\mathrm{NH}_{2} \mathrm{OH} \cdot \mathrm{HCl}$ in pyridine according to [43] and following Beckmann rearrangement of the crude oxime with thionyl chloride in dioxane at room temperature led to azepanone 7 (82\%), the following reduction with $\mathrm{LiAlH}_{4}$ in THF afforded azepano-20(S)hydroxy-dammar-24-en 8 (85\%). The structures of the target compounds were confirmed by NMR data. The presence of amide fragment in azepanone 7 was confirmed by the characteristic signal of $\mathrm{C} 3$ carbonyl carbon which was detected at $\delta 176.29 \mathrm{ppm}$. In the ${ }^{13} \mathrm{C}$ NMR spectrum of azepane 8 , the upfield shift of the carbonyl signal C3 to region $\delta 63.11 \mathrm{ppm}$ was observed. In the ${ }^{1} \mathrm{H}$ NMR spectra, the signal of methylene protons at $\mathrm{C} 3$ atom was registered at $\delta 3.19 \mathrm{ppm}$.

Thus, new amino-triterpenoids 4-6 and 8 have been synthesized for biological screening.

\section{Biological activity}

\section{Evaluation of antiviral activity}

Cytotoxicity and anti-influenza properties of the derivatives 4-6 and 8-19 were studied in MDCK cell culture against 


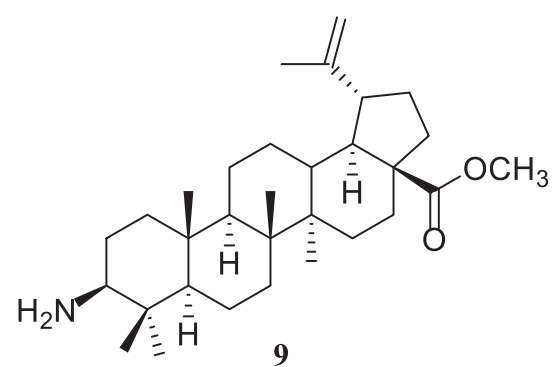

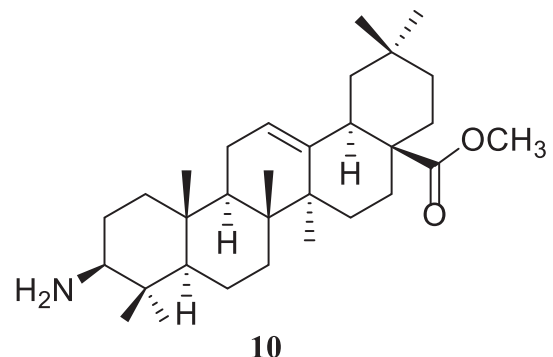

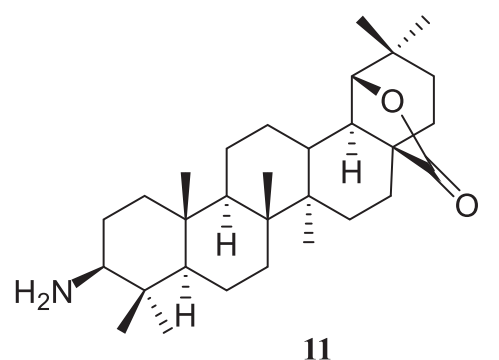<smiles>C=C(C)[C@H]1CCC2(CO)CC[C@H]3C(CCC4[C@@]3(C)CC[C@@H]3[C@@H](C)NCC[C@]43C)C12</smiles><smiles>C=C(C)[C@H]1CC[C@]2(C(=O)NC3CCCCC3)CC[C@]3(C)[C@@H](CC[C@H]4[C@@]5(C)CCCN[C@H](C)[C@H]5CC[C@]43C)C12</smiles>

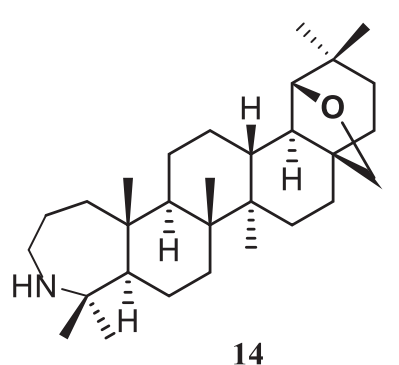

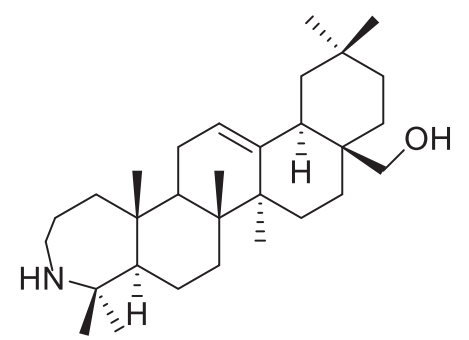

13

14

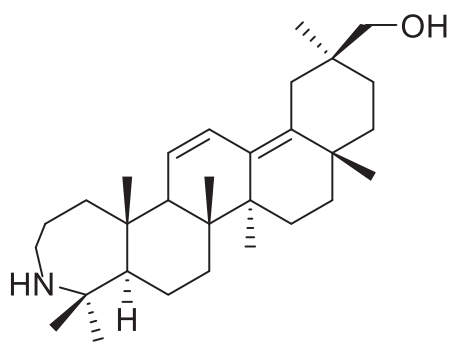

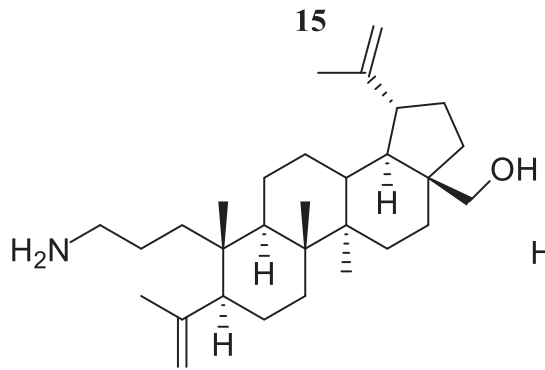

17

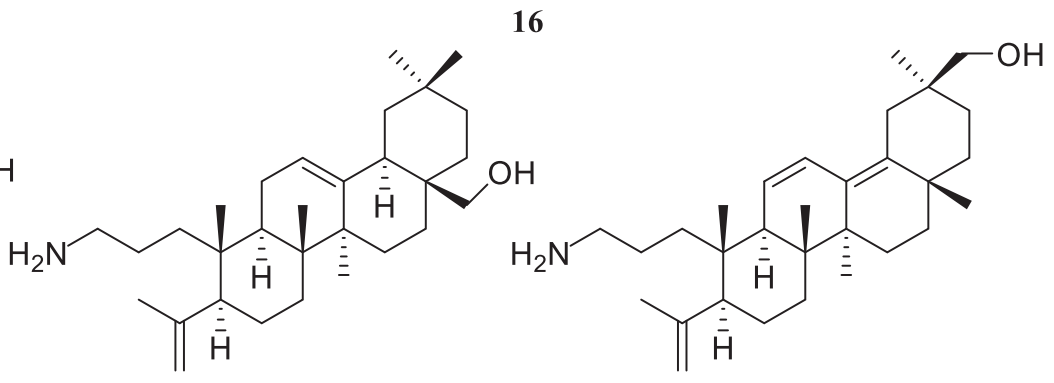

18
19

Fig. 1 The structures of compounds 9 [46], 10 [47], 11 [48], 12 [49], 13, 16, 18, 19 [50], 15 [51], 14 [52], 17 [53]

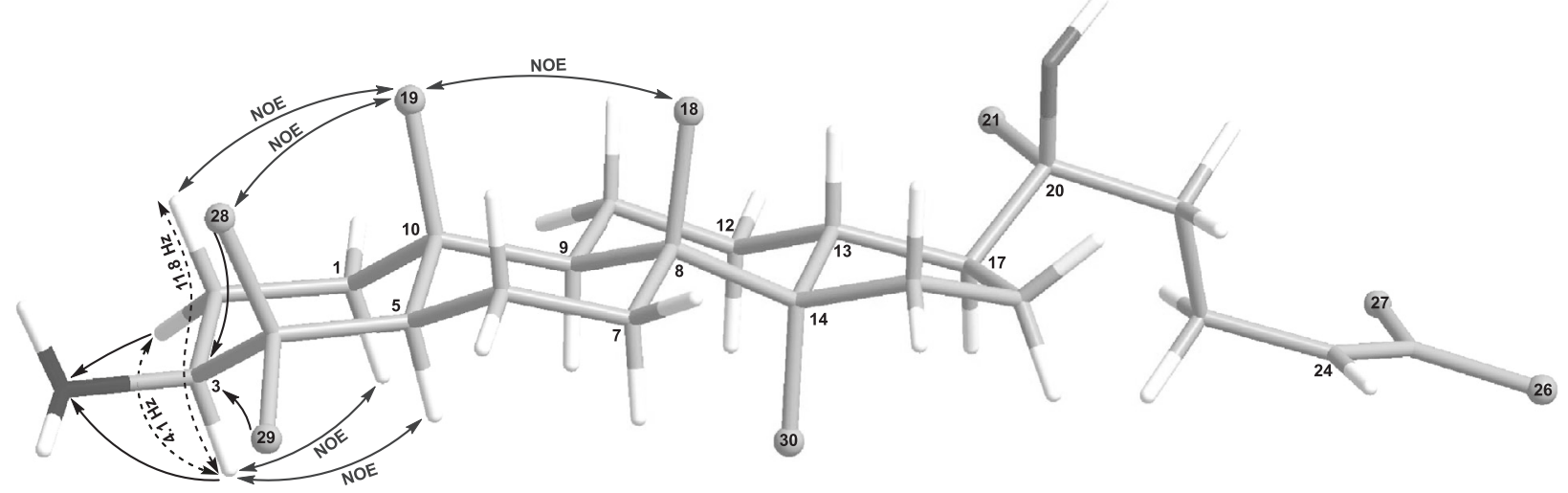

Fig. 2 Key NOESY, HMBC, and COSY correlations of compound 6 
Table 1 The antiviral activity of compounds 4-6 and 8-19 against Flu A H1N1

\begin{tabular}{lclc}
\hline Compound- $\mathrm{Mr}$ & $\mathrm{CC}_{50}, \mu \mathrm{M}^{\mathrm{a}}$ & $\mathrm{IC}_{50}, \mu \mathrm{M}^{\mathrm{b}}$ & $\mathrm{SI}^{\mathrm{c}}$ \\
\hline $\mathbf{4 - 5 3 6 . 4 6}$ & $46.6 \pm 3.1$ & $>18.7$ & 3 \\
$\mathbf{5 - 5 3 2 . 4 6}$ & $3.2 \pm 0.2$ & $>2.3$ & 1 \\
$\mathbf{6 - 4 4 3 . 7 6}$ & $13.5 \pm 0.8$ & $5.4 \pm 0.6$ & 3 \\
$\mathbf{8 - 4 4 4 . 4 1}$ & $\mathbf{2 1 . 9} \pm 1.1$ & $\mathbf{1 . 1} \pm 0.2$ & $\mathbf{1 9}$ \\
$\mathbf{9 - 4 6 9 . 3 9}$ & $20.0 \pm 1.4$ & $>7.9$ & 3 \\
$\mathbf{1 0 - 4 6 9 . 3 9}$ & $12.4 \pm 0.7$ & $>7.9$ & 2 \\
$\mathbf{1 1 - 4 5 5 . 3 8}$ & $\mathbf{2 7 . 0} \pm 1.3$ & $\mathbf{2 . 6} \pm 0.2$ & $\mathbf{1 0}$ \\
$\mathbf{1 2 - 4 4 1 . 4 0}$ & $2.1 \pm 0.1$ & $>0.8$ & 3 \\
$\mathbf{1 3 - 5 3 6 . 4 7}$ & $26.9 \pm 2.0$ & $>20.5$ & 1 \\
$\mathbf{1 4 - 4 4 1 . 4 0}$ & $46.7 \pm 2.2$ & $>24.9$ & 2 \\
$\mathbf{1 5 - 4 4 1 . 4 0}$ & $0.1 \pm 0.01$ & $0.04 \pm 0.01$ & 2 \\
$\mathbf{1 6 - 4 3 9 . 3 8}$ & $4.6 \pm 0.3$ & $>2.7$ & 2 \\
$\mathbf{1 7 - 4 4 1 . 4 0}$ & $3.2 \pm 0.2$ & $>2.9$ & 1 \\
$\mathbf{1 8 - 4 4 1 . 4 0}$ & $21.3 \pm 0.9$ & $>8.4$ & 3 \\
$\mathbf{1 9 - 4 3 9 . 3 8}$ & $10.2 \pm 0.7$ & $>6.8$ & 2 \\
Rimantadine & $62 \pm 4$ & $11 \pm 2$ & 6 \\
Oseltamivir carboxylate & $>200$ & $0.3 \pm 0.01$ & $>\mathbf{6 6 7}$ \\
\hline
\end{tabular}

${ }^{\mathrm{a}} \mathrm{CC}_{50}-50 \%$ cytotoxic concentration; ${ }^{\mathrm{b}} \mathrm{IC}_{50}-50 \%$ inhibitory concentration; ${ }^{\mathrm{c}} \mathrm{SI}-$ Selectivity index is defined as: $\mathrm{SI} \mathrm{CC}_{50} / \mathrm{IC}_{50}$. Bold values represent best results (SI value of 10 or higher)

influenza virus A/PuertoRico/8/34 (H1N1) Oseltamivir carboxylate was used as a reference compound. All results are summarized at Table 1 . As one can see, the tested compounds were of relatively high cytotoxicity their $\mathrm{CC}_{50}$ 's lying in one- to two-digits micromolar range. It was shown, in particular, that modification of the $\mathrm{C}-28$ position of lupane triterpenoids with the introduction of a cyclohexylamine substituent in compound $\mathbf{4}$ leads to a decrease in cytotoxicity by 1.7 times compared to $3 \beta$-amino-olean-28oate 9 containing a methoxy fragment. A similar situation is observed for amide 13, which is 13 times less toxic in comparison with azepanobetulin 12. Among the derivatives of the oleanane series, azepanoallobetulin 14 showed the lowest toxicity with $\mathrm{CC}_{50} 46.7 \mu \mathrm{M}$. The azepenouvaol 15 is the most toxic compound among all studied $\left(\mathrm{CC}_{50} 0.1 \mu \mathrm{M}\right)$, but transformation of ring $\mathrm{A}$ on 3,4-seco-3-amino in derivative 18 decreased toxicity by 200 -fold. The broadening of ring A from six-membered with 3-amino function to sevenmembered azepane in dammarane type derivatives one results in some decrease of toxicity (compound $\mathbf{6}$ and $\mathbf{8}$ ) from 13.5 to $21.9 \mu \mathrm{M}$.

For lupane, oleanane, and dammarane type derivatives 4-6 and 9-11 with the 3 $\beta$-amino group at $\mathrm{C} 3$ position the SI against $\mathrm{H} 1 \mathrm{~N} 1$ virus ranged from 1 to $10.3 \beta$-Amino-28-oxoallobetulin 11 with $\mathrm{IC}_{50} 2.6 \mu \mathrm{g} \mathrm{ml}^{-1}$ and SI 10 was established as the most active compound in this series.
Taking into account the potency of azepenotriterpenoids as biologically active platforms [31-33], anti-influenza activity of A-azepanodipterocarpol 8, azepanobetulin 12, azepanobetulin-28-cyclohexylcarboxamide 13, azepanoallobetulin 14, azepanouvaol 15 and azepanoglycyrrhetol 16 were tested and SI values from 1 to 3 was established. The combination of the A-azepano fragment and the dammarane frame led to the best results in terms of antiinfluenza activity and only A-azepanodipterocarpol $\mathbf{8}$ showed a good level of $\mathrm{IC}_{50} 1.1 \mu \mathrm{g} \mathrm{ml}^{-1}$ and SI 19 being a lead compound in this series.

Earlier, examples of the high antiviral activity of triterpenoid seco derivatives are presented [34-39]. Unfortunately, in contrast to the above data, 3,4-seco-3-aminoderivatives 16-19 were practically inactive against Flu A with SI values from 1 to 3. 3,4-Seco-3-amino-30-hydroxyolean-12(13)-en 18 was a more active compound in this series with $\mathrm{IC}_{50}>8.4$ and SI 3 . In this case, due to the small sample of compounds, it is impossible to say unequivocally about the inefficiency of the synthesis of seco-amino derivatives. It is also necessary to modify the 3 -amino group of the fragment and further assessment of the structure-activity relationship of the obtained derivatives.

In summary, among tested nitrogen-containing lupane-, oleanane- and dammarane-based triterpenoids, azepanodipterocarpol $\mathbf{8}$ and 3 $\beta$-amino-28-oxo-allobetulin $\mathbf{1 1}$ demonstrated a high inhibitory activity against $\mathrm{H} 1 \mathrm{~N} 1$ virus with $\mathrm{IC}_{50} 1.1,2.6 \mu \mathrm{g} \mathrm{ml}^{-1}$ and SI 19 and 10, respectively. It was established that introduction of A-azepano-ring fragment into dipterocarpol derivative with a native side chain results in an enhancing effect on the antiviral activity.

In conclusion, we have synthesized novel, previously unknown, derivatives of lupane-, oleanane-, and dammarane-based triterpenoids. Among them, dipterocarpol was shown to be a promising scaffold to produce novel $\mathrm{N}$-containing bioactive derivatives including antiviral agents. Based on the results presented, focusing of the chemical library with further modification of A-azepanodipterocarpol in the side chain and synthesis of acylates on cycle A and study of structure-activity relation will lead to new effective compounds with high anti-viral activity.

Despite inspiring results, several questions should be addressed at the next stages of the characteristic of virusinhibiting properties of triterpenes. First, in the present study we demonstrate the anti-viral potential of triterpenes against influenza virus based on the results of CPE reduction assay with two lead compounds, 8 and 11, identified. Their activity should be further studied by virus yield reduction assay to demonstrate their direct anti-viral action to rule out non-selective cytoprotective or antioxidant activity. 
Second, in our experiments we used influenza virus A/ PuertoRico/8/34 which is relatively old in terms of antigenic properties comparing to viruses currently circulating among humans. The spectrum of activity of lead compound $\mathbf{8}$ or its more active analog synthesized after focusing of chemical library, must be assessed using influenza viruses of A and B types, and different subtypes (H1, H3, H5, etc.) including contemporary isolates of influenza viruses.

Third, the virus we used in our study is resistant to adamantane derivatives, Rimantadine, the well-known blocker of virally encoded proton channel M2. This was confirmed by demonstrating the low activity of Rimantadine in our experiments $(\mathrm{SI}=5$, Table 1$)$. The activity of triterpene derivatives $\mathbf{8}$ and $\mathbf{1 1}$ is higher suggesting that their target differs from M2 protein.

Finally, in the presented study we have demonstrated just the total virus-suppressing activity of compounds. The specific target and mechanism(s) of virus-inhibiting action of lead compounds as well as the ability of viral resistance development, should be assessed in further studies for possible development of novel antivirals. This will be a subject of further virology-oriented experiments.

\section{Experimental}

\section{General}

The spectra were recorded at the Center for the Collective Use "Chemistry" of the Ufa Institute of Chemistry of the UFRC RAS and RCCU "Agidel" of the UFRC RAS. ${ }^{1} \mathrm{H}$ and ${ }^{13} \mathrm{C}$ NMR spectra were recorded on a "Bruker AM500" (Bruker, Billerica, MA, USA, 500 and $125.5 \mathrm{MHz}$ respectively, $\delta, \mathrm{ppm}, \mathrm{Hz}$ ) in $\mathrm{CDCl}_{3}$, internal standard tetramethylsilane. Mass spectra were obtained on a liquid chromatograph-mass spectrometer LCMS-2010 EV (Shimadzu, Kyoto, Japan). Melting points were detected on a micro table "Rapido PHMK05" (Nagema, Dresden, Germany). Optical rotations were measured on a polarimeter "Perkin-Elmer 241 MC" (Perkin Elmer, Waltham, MA, USA) in a tube length of $1 \mathrm{dm}$. Elemental analysis was performed on a Euro EA-3000 CHNS analyzer (Eurovector, Milan, Italy); the main standard is acetanilide. Thin-layer chromatography analyses were performed on Sorbfil plates (Sorbpolimer, Krasnodar, Russian Federation), using the solvent system chloroform-ethyl acetate, 40:1. Substances were detected by $10 \% \mathrm{H}_{2} \mathrm{SO}_{4}$ with subsequent heating to $100-120^{\circ} \mathrm{C}$ for $2-3 \mathrm{~min}$. Compounds $\mathbf{1}$ [41], 2 [42], 3 [43], 9 [46], 10 [47], 11 [48], 12 [49], 13, 16, 18, 19 [50], 15 [51], 14 [52], 17 [53] were prepared by the literature methods. Dipterocarpol 3 was isolated from Dipteocarpus alatus collected in Quang Nam province of Vietnam and it spectral and physicochemical data was coincided with the literature [43]. Experimental details of new compounds relating to this paper are available in the Supplementary material (Figures S1-S9).

\section{Chemistry}

\section{Synthesis of compounds (4-6)}

To solution of $\mathrm{CH}_{3} \mathrm{COONH}_{4}(2 \mathrm{mmol}, 0.8 \mathrm{~g})$ in $\mathrm{CH}_{3} \mathrm{OH}$ $(25 \mathrm{ml}) \mathrm{NaBH}_{3} \mathrm{CN}(0.6 \mathrm{mmol}, 0.1 \mathrm{~g})$ was added. The reaction mixture was stirred at $12 \mathrm{~h}$ at room temperature, on completion of the reaction $1 \mathrm{M}$ solution of $\mathrm{NaOH}(30 \mathrm{ml})$ was added, the precipitate was filtered off, washed until $\mathrm{pH}$ 7. The residue was purified by column chromatography on $\mathrm{SiO}_{2}$; the product was eluted with $\mathrm{CHCl}_{3}, \mathrm{CHCl}_{3}-\mathrm{EtOH}$ (from 40:1 to 40:3).

\section{$N$-[3ß-amino-lup-20(29)-en-28-oyl]cyclohexylamine (4)}

Yield $86 \%(0.46 \mathrm{~g})$; m. p. $124-125^{\circ} \mathrm{C} ;[\alpha]_{\mathrm{D}}{ }^{20}+45^{\circ}(c 0.1$, $\left.\mathrm{CHCl}_{3}\right) ; \delta_{H}\left(500.13 \mathrm{MHz}, \mathrm{CDCl}_{3}\right) 0.75,0.93,0.98,1.09$, $1.12,1.68\left(6 \mathrm{~s}, 18 \mathrm{H}, \mathrm{CH}_{3}\right), 1.01-1.60\left(\mathrm{~m}, 4 \mathrm{H}, \mathrm{CH}_{2}\right)$, 1.60-2.00 (m, 25H, CH, $\left.\mathrm{CH}_{2}, \mathrm{NH}_{2}\right), 2.17-2.19(\mathrm{~m}, 5 \mathrm{H}, \mathrm{CH}$, $\left.\mathrm{CH}_{2}\right), 2.20\left(\mathrm{dd}, 1 \mathrm{H}, J=3.8, J=11.8, \mathrm{H}_{\mathrm{ax}}-3\right), 2.40-2.52(\mathrm{~m}$, $2 \mathrm{H}, \mathrm{H} 16), 3.14$ (td, $1 \mathrm{H}, J=4.3, J=11.2, \mathrm{H}-19), 3.73$ (m, $\left.1 \mathrm{H}, \mathrm{H}-1^{\prime}\right), 4.57$ and 4.72 (both br.s, 2H, H-29), 5.43 (d, 1H, $J=7.8, \mathrm{CONH}) ; \delta_{C}\left(125.76 \mathrm{MHz}, \mathrm{CDCl}_{3}\right) 14.52,15.63$, $15.84,19.49,20.30,21.77,22.34,24.90,24.98,25.64$ (2 C), $29.29,29.37,29.68,30.86,32.93,33.07,33.28,33.73$, $36.55,37.77,38.44,40.59,42.51,44.48,45.27,46.83$, 47.70, 48.47, 50.04, 52.82, 55.43, 55.67 (C-3), 109.29, 151.01, $175.11(\mathrm{CONH})$; MS (APCI) $m / z 537.46[\mathrm{M}+\mathrm{H}]^{+}$ (calcd for $\mathrm{C}_{36} \mathrm{H}_{60} \mathrm{~N}_{2} \mathrm{O}$, 536.46). Anal. Calcd for $\mathrm{C}_{36} \mathrm{H}_{60} \mathrm{~N}_{2} \mathrm{O}$ : C, 80.54; H, 11.26; N, 5.22. Found: C, 80.23; H, 10.98; $\mathrm{N}, 5.03$.

\section{$N$-[3 3 -amino-olean-12(13)-en-28-oyl]-2- aminopyridineamine (5)}

Yield $82 \%(0.43 \mathrm{~g}) ;$ m. p. $156-157^{\circ} \mathrm{C} ;[\alpha]_{\mathrm{D}}{ }^{20}+51^{\circ}(c 0.1$, $\left.\mathrm{CHCl}_{3}\right) ; \delta_{H}\left(500.13 \mathrm{MHz}, \mathrm{CDCl}_{3}\right) 0.63,0.82,0.87,0.92$, $0.93,1.21\left(6 \mathrm{~s}, 18 \mathrm{H}, \mathrm{CH}_{3}\right), 1.01-1.48\left(\mathrm{~m}, 4 \mathrm{H}, \mathrm{CH}_{2}\right)$, 1.50-2.17 (m, 25H, CH, $\left.\mathrm{CH}_{2}, \mathrm{NH}, \mathrm{NH}_{2}\right), 2.72(\mathrm{dd}, 1 \mathrm{H}, J=$ $\left.4.3, J=11.9, \mathrm{H}_{\mathrm{ax}}-3\right), 5.53$ (t, $\left.1 \mathrm{H}, J=7.0, \mathrm{H}-12\right), 6.90-8.31$ $\left(\mathrm{m}, 4 \mathrm{H}, \mathrm{H}_{\text {arom }}\right) ; \delta_{C}\left(125.76 \mathrm{MHz}, \mathrm{CDCl}_{3}\right) 15.30,15.80$, $16.13,17.17,19.02,19.50,20.88,21.23,22.86,24.92$, $25.00,25.66,27.22,29.36,30.94,32.96,33.30,33.79$, $34.01,37.27,37.84,38.48,40.36,40.83,42.48,46.90$, 47.68, 50.14, 50.25, 55.43, 55.67 (C-3), 109.29, 151.01, $175.11(\mathrm{CONH}) ; \quad \mathrm{MS} \quad(\mathrm{APCI}) \mathrm{m} / \mathrm{z} 532.46 \quad[\mathrm{M}+\mathrm{H}]^{+}$ (calcd for $\mathrm{C}_{35} \mathrm{H}_{53} \mathrm{~N}_{3} \mathrm{O}, 531.42$ ). Anal. Calcd for $\mathrm{C}_{35} \mathrm{H}_{53} \mathrm{~N}_{3} \mathrm{O}$ : C, 79.05; H, 10.05; N, 7.90. Found: C, 78.95; H, 9.80; $\mathrm{N}, 7.76$. 


\section{3-Amino-20(S)-hydroxy-dammar-24-en (6)}

Yield $89 \%\left(0.39\right.$ g) ; m. p. $168{ }^{\circ} \mathrm{C} ;[\alpha]_{\mathrm{D}}{ }^{20}+34^{\circ}(c) 0.1$, $\left.\mathrm{CHCl}_{3}\right) ; \delta_{H}\left(500.13 \mathrm{MHz}, \mathrm{CDCl}_{3}\right) 0.73(\mathrm{~s}, 3 \mathrm{H}, \mathrm{H}-28), 0.74$ $\left(\mathrm{dd}, 1 \mathrm{H},{ }^{3} J_{5-6 \mathrm{ax}}=11.7,{ }^{3} J_{5-6 \mathrm{eq}}=2.2, \mathrm{H}-5\right), 0.83$ (s, $\left.3 \mathrm{H}, \mathrm{H}-19\right)$, 0.88 (s, 3H, H-30), 0.94 (s, 3H, H-29), 0.96 (s, 3H, H-18), $0.97\left(\mathrm{ddd}, 1 \mathrm{H},{ }^{2} J=12.7,{ }^{3} J_{1 \mathrm{ax}-2 \mathrm{ax}}=12.4,{ }^{3} J_{1 \mathrm{ax}-2 \mathrm{eq}}=4.1, \mathrm{H}_{\mathrm{ax}}{ }^{-}\right.$ 1), $1.06\left(\mathrm{~m}, 1 \mathrm{H}, \mathrm{H}_{\alpha}-15\right), 1.14(\mathrm{~s}, 3 \mathrm{H}, \mathrm{H}-21), 1.23\left(\mathrm{~m}, 1 \mathrm{H}, \mathrm{H}_{\mathrm{ax}^{-}}\right.$ 11), $1.26\left(\mathrm{~m}, 1 \mathrm{H}, \mathrm{H}_{\mathrm{ax}}-12\right), 1.27\left(\mathrm{~m}, 1 \mathrm{H}, \mathrm{H}_{\mathrm{eq}}-7\right), 1.33(\mathrm{dd}, 1 \mathrm{H}$, $\left.{ }^{3} J_{9-11 \mathrm{ax}}=11.6,{ }^{3} J_{9-11 \mathrm{eq}}=2.8, \mathrm{H}-9\right), 1.43\left(\mathrm{~m}, 1 \mathrm{H}, \mathrm{H}_{\mathrm{ax}}-6\right), 1.45$ (tdd, $1 \mathrm{H},{ }^{2} J=12.4,{ }^{3} J_{2 \mathrm{ax}-1 \mathrm{ax}}=12.4,{ }^{3} J_{2 \mathrm{ax}-3}=11.9,{ }^{3} J_{2 \mathrm{ax}-\mathrm{leq}}=$ 3.6, $\left.\mathrm{H}_{\mathrm{ax}}-2\right), 1.46\left(\mathrm{~m}, 1 \mathrm{H}, \mathrm{H}_{\beta}-15\right), 1.47$ (t, 2H, H-22), 1.49 (m, $\left.1 \mathrm{H}, \mathrm{H}_{\beta}-16\right), 1.50\left(\mathrm{~m}, 1 \mathrm{H}, \mathrm{H}_{\mathrm{eq}}-11\right), 1.53\left(\mathrm{~m}, 1 \mathrm{H}, \mathrm{H}_{\mathrm{ax}}-7\right), 1.55$ (dtd, $1 \mathrm{H},{ }^{2} J=12.4,{ }^{3} J_{2 \mathrm{eq}-3}=4.1,{ }^{3} J_{2 \mathrm{eq}-1 \mathrm{x}}=4.1,{ }^{3} J_{2 \mathrm{eq}-\mathrm{leq}}=$ 3.6, $\left.\mathrm{H}_{\mathrm{eq}}-2\right), 1.55\left(\mathrm{~m}, 1 \mathrm{H}, \mathrm{H}_{\mathrm{eq}}-6\right), 1.62\left(\mathrm{~d}, 3 \mathrm{H},{ }^{4} J_{26-24}=1.5, \mathrm{H}-\right.$ 27), $1.63\left(\mathrm{ddd}, 1 \mathrm{H},{ }^{3} J_{13-17}=12.6,{ }^{3} J_{13-12 \mathrm{ax}}=10.2,{ }^{3} J_{13-12 \mathrm{eq}}=\right.$ $3.5, \mathrm{H}-13), 1.67\left(\mathrm{dt}, 1 \mathrm{H},{ }^{2} J=12.7,{ }^{3} J_{\text {leq-2ax }}=3.6,{ }^{3} J_{\text {leq-2eq }}=\right.$ 3.6, $\left.\mathrm{H}_{\mathrm{eq}}-1\right), 1.69\left(\mathrm{~d}, 3 \mathrm{H},{ }^{4} \mathrm{~J}_{27-24}=1.5, \mathrm{H}-26\right), 1.72(\mathrm{~m}, 1 \mathrm{H}$, $\left.\mathrm{H}_{\mathrm{\alpha}}-16\right), 1.74$ (m, 1H, H-17), 1.82 (m, 1H, $\left.\mathrm{H}_{\mathrm{eq}}-12\right), 2.04$ (m, $\left.1 \mathrm{H}, \mathrm{H}_{\mathrm{A}}-23\right), 2.06\left(\mathrm{~m}, 1 \mathrm{H}, \mathrm{H}_{\mathrm{B}}-23\right), 2.34\left(\mathrm{dd}, 1 \mathrm{H},{ }^{3} J_{3-2 \mathrm{ax}}=\right.$ $\left.11.9,{ }^{3} J_{3-2 \mathrm{eq}}=4.1, \mathrm{H}-3\right), 5.12\left(\mathrm{~m}, 1 \mathrm{H},{ }^{3} J_{24-23}=7.1,{ }^{4} J_{24-26}=\right.$ $\left.1.5,{ }^{4} J_{24-27}=1.5, \mathrm{H}-24\right) ; \delta_{C}\left(125.76 \mathrm{MHz}, \mathrm{CDCl}_{3}\right) 15.51(\mathrm{C}-$ 28), 15.51 (C-18),16.13 (C-19),16.46 (C-30), 17.71 (C-27), 18.63 (C-6), 21.46 (C-11), 22.56 (C-23), 24.82 (C-16), 25.40 (C-21), 25.74 (C-26), 27.56 (C-12), 27.98 (C-2), 28.33 (C29), 31.18 (C-15), 35.29 (C-7), 37.30 (C-10), 38.30 (C-4), 39.71 (C-1), 40.31 (C-8), 40.54 (C-22), 42.30 (C-13), 49.85 (C-17), 50.30 (C-14), 50.74 (C-9), 56.53 (C-5), 59.74 (C-3), 75.33 (C-20), 124.77 (C-24), $131.52(\mathrm{C}-25) ; \delta_{N}(50.68 \mathrm{MHz}$, $\left.\mathrm{CDCl}_{3}\right) 31.06\left(\mathrm{NH}_{2}\right) ; \mathrm{MS}\left(\right.$ APCI) $\mathrm{m} / z 444.76[\mathrm{M}+\mathrm{H}]^{+}$ (calcd for $\mathrm{C}_{30} \mathrm{H}_{53} \mathrm{NO}$, 443.76). Anal. Calcd for $\mathrm{C}_{30} \mathrm{H}_{53} \mathrm{NO}$ : C, 81.20; H, 12.04; N, 3.16. Found: C, 81.03; H, 11.98; $\mathrm{N}, 3.07$.

\section{3-0xo-3a-aza-20(S)-hydroxy-dammar-24-en (7)}

3-Oximino-dipterocarpol [43] $(1 \mathrm{mmol}, 0.44 \mathrm{~g})$ in dry dioxane $(15 \mathrm{ml})$ was treated with $\mathrm{SOCl}_{2}(0.4 \mathrm{ml})$, stirred at room temperature for $30 \mathrm{~min}$, and poured into $\mathrm{H}_{2} \mathrm{O}(50 \mathrm{ml})$. The precipitate was filtered off and purified by column chromatography on $\mathrm{SiO}_{2}$ with $n-\mathrm{C}_{6} \mathrm{H} 12, n-\mathrm{C}_{6} \mathrm{H}_{12}-\mathrm{EtOAc}$ (4:1), and $\mathrm{CHCl}_{3}$ as eluents. Yield $0.41 \mathrm{~g} \mathrm{(82 \% ),} \mathrm{m.p.} 261^{\circ}$ $\mathrm{C},[\alpha]_{D}{ }^{20}+18^{\circ}\left(c 0.1, \mathrm{CHCl}_{3}\right) ; \delta_{H}\left(500.13 \mathrm{MHz}, \mathrm{CDCl}_{3}\right)$ $0.80,0.93,0.98,1.08,1.16,1.24,1.55,1.62(8 \mathrm{~s}, 24 \mathrm{H}$, $\left.8 \mathrm{CH}_{3}\right), 1.30-1.50\left(\mathrm{~m}, 12 \mathrm{H}, \mathrm{CH}, \mathrm{CH}_{2}\right), 1.65-1.82(\mathrm{~m}, 9 \mathrm{H}$, $\left.\mathrm{CH}, \mathrm{CH}_{2}\right), 1.94-2.04(\mathrm{~m}, 2 \mathrm{H}, \mathrm{H}-23), 2.24-2.33(\mathrm{~m}, 1 \mathrm{H}$, $\left.\mathrm{H}_{\mathrm{ax}}-2\right), 2.41-2.49\left(\mathrm{~m}, 1 \mathrm{H}, \mathrm{H}_{\mathrm{eq}}-2\right), 5.05(\mathrm{t}, 1 \mathrm{H}, J=6.8, \mathrm{H}-$ 24), $5.68(\mathrm{~m}, 1 \mathrm{H}, \mathrm{CONH}) ; \delta_{C}\left(125.76 \mathrm{MHz}, \mathrm{CDCl}_{3}\right) 15.10$, $16.14,17.69,18.17,22.54$ (2C), 24.72, 25.42, 25.72, $27.28,27.68,30.99,32.07,33.23,34.56,39.59,40.04$, $40.02,40.59,42.37,49.54,50.25,51.10$ (2 C), 53.33, 56.20, 75.11 (C-20), 124.73 (C-24), 131.42 (C-25), 176.29 $(\mathrm{CONH}) ; \mathrm{MS}$ (APCI) $\mathrm{m} / z 458.39[\mathrm{M}+\mathrm{H}]^{+}$(calcd for
$\mathrm{C}_{30} \mathrm{H}_{51} \mathrm{NO}_{2}$, 457.39). Anal. Calcd for $\mathrm{C}_{30} \mathrm{H}_{51} \mathrm{NO}_{2}$ : C, 78.72; H, 11.23; N, 3.05. Found: C, 78.43; H, 11.14; N, 2.98 .

\section{3-Deoxy-3a-homo-3a-aza-20(S)-hydroxy-dammar-24-en (8)}

To a solution of compound 7 ( $1 \mathrm{mmol}, 0.45 \mathrm{~g})$ in dry THF $(20 \mathrm{ml})(2.2 \mathrm{mmol}, 0.07 \mathrm{~g}) \mathrm{LiAlH}_{4}$ was added, and the mixture was refluxed for $1 \mathrm{~h}$, then $\mathrm{H}_{2} \mathrm{O}(20 \mathrm{ml})$ and $10 \%$ $\mathrm{HCl}(10 \mathrm{ml})$ were added dropwise. The mixture was extracted with $\mathrm{CHCl}_{3}(3 \times 20 \mathrm{ml})$, the organic layer was washed with water and dried over $\mathrm{CaCl}_{2}$. The solvent was removed under reduced pressure, the residue was purified by column chromatography on $\mathrm{SiO}_{2}$ with $\mathrm{CHCl}_{3}, \mathrm{CHCl}_{3^{-}}$ EtOH (50:1, 25:1) as eluents. Yield 62\% (0.27 g); m.p. $102^{\circ}$ $\mathrm{C} ;[\alpha]_{D}{ }^{20}+114^{\circ}\left(c 0.1, \mathrm{CHCl}_{3}\right) ; \delta_{H}\left(500.13 \mathrm{MHz}, \mathrm{CDCl}_{3}\right)$ $0.80,0.96,0.97,1.03,1.18,1.21,1.51,1.60(8 \mathrm{~s}, 24 \mathrm{H}$, $\left.8 \mathrm{CH}_{3}\right), 1.62-2.00\left(\mathrm{~m}, 16 \mathrm{H}, \mathrm{CH}, \mathrm{CH}_{2}\right), 2.00-2.51(\mathrm{~m}, 10 \mathrm{H}$, $\mathrm{CH}, \mathrm{CH}_{2}$ ), 3.19 (m, 2H, H-3), 5.51 (br.s, $\left.1 \mathrm{H}, \mathrm{H}-24\right) ; \delta_{C}$ $\left(125.76 \mathrm{MHz}, \mathrm{CDCl}_{3}\right) 15.26,15.63,15.80,17.72,18.29$, $22.48,22.60,25.15,25.71,27.02,27.46,28.84,31.12$, $32.08,33.32,34.12,34.79,39.72,40.16,40.33,45.45$, $47.52,49.40,51.47,53.28,56.22,63.11,75.33,124.39$ (C24), 131.47 (C-25); MS (APCI) $\mathrm{m} / z 444.41[\mathrm{M}+\mathrm{H}]^{+}$ (calcd for $\mathrm{C}_{30} \mathrm{H}_{53} \mathrm{NO}, 443.41$ ). Anal. Calcd for $\mathrm{C}_{30} \mathrm{H}_{53} \mathrm{NO}$ : C, 81.20; H, 12.04; N, 3.16. Found: C, 81.01; H, 11.87; N, 3.03.

\section{Biology}

\section{Viruses and cells}

Influenza virus A/Puerto Rico/8/34 (H1N1) was obtained from the collection of viruses of St. Petersburg Pasteur Institute. Before the experiment, virus was propagated in the allantoic cavity of 10- to 12-day-old chicken embryos for $48 \mathrm{~h}$ at $36^{\circ} \mathrm{C}$. The infectious titer of the virus was determined in Madin-Darby Canine Kidney (MDCK) cells (ATCC \# CCL-34) grown in 96-well plates in alpha-MEM medium with $10 \%$ fetal bovine serum.

\section{Cytotoxicity assay}

MDCK cells were seeded onto 96-well culture plates $\left(10^{4}\right.$ cells per well) and incubated at $36^{\circ} \mathrm{C}$ in $5 \% \mathrm{CO}_{2}$ until continuous monolayer formation. To assess the toxicity of compounds, a series of their 3-fold dilutions at concentrations of 300 to $4 \mu \mathrm{g} \mathrm{ml}^{-1}$ in Eagle's Minimal Essential Medium (MEM) were prepared. The dilutions were added to the wells of the plates. Cells were incubated for $72 \mathrm{~h}$ at $36{ }^{\circ} \mathrm{C}$ in a $\mathrm{CO}_{2}$ incubator under $5 \% \mathrm{CO}_{2}$. Further, a microtetrazolium (MTT) assay was performed on 96-well plates. The cells were washed 2 times with saline $(0.9 \% \mathrm{NaCl})$, and $100 \mu \mathrm{l} /$ well of MTT solution [3(4,5-dimethylthiazol-2-yl)-2,5-diphenyltetrazolium bromide] at 
a concentration of $0.5 \mu \mathrm{g} \mathrm{ml}^{-1}$ in MEM was added. The plates were incubated for $1 \mathrm{~h}$ at $36^{\circ} \mathrm{C}$, the liquid was removed, and dimethylsulfoxide (DMSO) $(0.1 \mathrm{ml}$ per well) was added. The optical density (OD) of the cells was measured on a Thermo Multiskan FC spectrophotometer (Thermo Fisher Scientific, USA) at a wavelength of $540 \mathrm{~nm}$. Based on the obtained data, the $\mathrm{CC}_{50}$, the concentration of the compound that destroys $50 \%$ of the cells in the culture, was calculated for each specimen.

\section{CPE reduction assay}

The compounds in appropriate concentrations were added to MDCK cells $(0.1 \mathrm{ml}$ per well). MDCK cells were further infected with A/Puerto Rico/8/34 (H1N1) influenza virus (m.o.i 0.01). Plates were incubated for $72 \mathrm{~h}$ at $36{ }^{\circ} \mathrm{C}$ at $5 \% \mathrm{CO}_{2}$. After that, cell viability was assessed by the MTT test, as described above. The cytoprotective activity of compounds was considered as their ability to increase the values of the OD compared to the control wells (with virus only; no drugs). Based on the obtained results, the $\mathrm{IC}_{50}$ values, i.e., the concentration of compounds that results in $50 \%$ cell protection, were calculated using GraphPad Prism software. $\mathrm{IC}_{50}$ values in $\mu \mathrm{g} \mathrm{ml}^{-1}$ were then calculated into micromoles. For each compound, the value of the selectivity index (SI) was calculated as a ratio of $\mathrm{CC}_{50}$ to $\mathrm{IC}_{50}$.

\section{Conclusions}

In conclusion, the synthesis and evaluation of the in vitro anti-influenza activities of lupane, oleanane, and dammarane type A-amino derivatives was performed. The primary assay of tested triterpenoids against Flu A H1N1 demonstrated their SI values ranged from 1 to 19 . Dammarane type A-azepanodipterocarpol showed the most significant antiviral activity against the pandemic influenza A virus $(\mathrm{H} 1 \mathrm{~N} 1)$, with an $\mathrm{IC}_{50}$ value of $1.1 \mu \mathrm{M}$ and SI 19.

Acknowledgements The reported study was performed under the e-Asia_Health and funded by RFBR project number 21-53-70201 (Russian), MOST (Vietnam), and MOE project number HE-098 (Myanmar).

\section{Compliance with ethical standards}

Conflict of interest The authors declare no competing interests.

Publisher's note Springer Nature remains neutral with regard to jurisdictional claims in published maps and institutional affiliations.

\section{References}

1. Guan Y, Gavin JDS. The emergence and diversification of panzootic $\mathrm{H}_{5} \mathrm{~N}_{1}$ influenza viruses. Virus Res. 2013;178:35-43. https:// doi.org/10.1016/j.virusres.2013.05.012

2. Zhu HC, Lam TTY, Smith DK, Guan Y. Emergence and development of H7N9 influenza viruses in China. Curr Opin Virol. 2016;16:106-13. https://doi.org/10.1016/j.coviro.2016. 01.020

3. Drosten C, Gunther S, Preiser W, Werf S, Brodt H, Becker S, et al. Identification of a novel coronavirus in patients with severe acute respiratory syndrome. N. Engl J Med. 2003;348:1967-76. https://doi.org/10.1056/nejmoa030747

4. Holmes EC, Dudas G, Rambaut A, Andersen KG. The evolution of Ebola virus: insights from the 2013-2016 epidemic. Nature. 2016;538:193-200. https://doi.org/10.1038/nature19790

5. Zaki AM, Boheemen S, Bestebroer TM, Osterhaus ADME, Fouchier RAM. Isolation of a novel coronavirus from a man with pneumonia in Saudi Arabia. N. Engl J Med. 2012;367:1814-20. https://doi.org/10.1056/nejmoa1211721

6. Chen Y, Scieux C, Garrait V, Socié G, Rocha V, Molina J, et al. Resistant herpes simplex virus type 1 infection: an emerging concern after allogeneic stem cell transplantation. Clin Infect Dis. 2000;31:927-35. https://doi.org/10.1086/314052

7. World Health Organization. Influenza (Avian and Other Zoonotic). https://www.who.int/n/news-room/fact-sheets/detail/influenza-(avia n-and-other-zoonotic) (accessed 13 November 2018).

8. Enserink M, Cohen J. Virus of the year. The novel $\mathrm{H}_{1} \mathrm{~N}_{1}$ influenza. Science. 2009;326:1607 https://doi.org/10.1126/science. 326.5960 .1607

9. Moscona A. Global transmission of Oseltamivir-resistant influenza. N. Engl J Med. 2009;360:953-6. https://doi.org/10.1056/ nejmp0900648

10. Kalil AC, Thomas PG. Influenza virus-related critical illness: pathophysiology and epidemiology. Crit Care Med. 2019;23:258 https://doi.org/10.1186/s13054-019-2539-x

11. Potterat $\mathrm{O}$, Hamburger M. Drug discovery and development with plant-derived compounds. Nat Compd Drugs. 2008;1:45-118. https://doi.org/10.1007/978-3-7643-8117-2_2

12. Nakamura H. Plant-derived triterpenoid biomarkers and their applications in paleoenvironmental reconstructions: chemotaxonomy, geological alteration, and vegetation reconstruction. Res Org Geochem. 2019;35:11-35.

13. Loc TV, Quynh NVT, Chien TV, Phuong TTT, Ninh PT, Thanh NT, et al. Synthesis of Asiatic acid derivatives and their cytotoxic activity. Med Chem Res. 2018;27:1609-23. https://doi.org/10. 1007/s00044-018-2176-y

14. Hernández-Vázquez L, Palazón Barandela J, Navarro-Ocaña, A, The pentacyclic triterpenes $\alpha, \beta$-amyrins: a review of sources and biological activities. Chapter 23 in: Rao, Venketeshwer. 2012. Phytochemicals: a global perspective of their role in nutrition and health. IntechOpen. ISBN: 978-953-51-4317-8. 2012: 487-502. https://doi.org/10.5772/1387

15. Xiao S, Tian Z, Wang Y, Si L, Zhang L, Zhou D. Recent progress in the antiviral activity and mechanism study of pentacyclic triterpenoids and their derivatives. Med Res Rev. 2018;38:951-76. https://doi.org/10.1002/med.21484

16. Baltina LA, Hour M-J, Liu Y-C, Chang Y-S, Huang S-H, Lai H$\mathrm{C}$, et al. Antiviral activity of glycyrrhizic acid conjugates with amino acid esters against Zika virus. Virus Res. 2021. https://doi. org/10.1016/j.virusres.2020.198290

17. Vaidya KA, Kadam AV, Nema V. Anti-retroviral drugs for HIV: old and new. Austin J HIV/AIDS Res. 2016;3:1026. 
18. Li JY, Cao HY, Liu P, Cheng GH, Sun MY. Glycyrrhizic acid in the treatment of liver diseases: literature review. Biomed Res Int. 2014;2014:872139 https://doi.org/10.1155/2014/872139

19. Li H, Cheng C, Li S, Wu Y, Liu Z, Liu M, et al. Discovery and structural optimization of 3-O-b-chacotriosyl oleanane-type triterpenoids as potent entry inhibitors of SARS-CoV-2 virus infections. Eur J Med Chem. 2021;215:113242 https://doi.org/10. 1016/j.ejmech.2021.113242

20. Molina-Salinas GM, Bórquez J, Ardiles A, Said-Fernández S, Loyola LA, San-Martín A, et al. Antituberculosis activity of natural and semisynthetic azorellane and mulinane diterpenoids. Fitoterapia. 2010;81:50-54. https://doi.org/10.1016/j.fitote.2009.07.005

21. Flekhter OB, Boreko EI, Nigmatullina LR, Tret'yakova EV, Pavlova NI, Baltina LA, et al. Synthesis and antiviral activity of lupane triterpenoids and their derivatives. Pharm Chem Jl. 2004;38:355-8. https://doi.org/10.1023/B:PHAC.0000048431. 65649.bd

22. Flekhter OB, Boreko EI, Nigmatullina LR, Tret'yakova EV, Pavlova NI, Baltina LA, et al. Synthesis and antiviral activity of ureides and carbamates of betulinic acid and its derivatives. Russ $\mathbf{J}$ Bioorg Chem. 2003;29:594-600. https://doi.org/10.1023/B:RUBI. 0000008902.36604 .97

23. Flekhter OB, Medvedeva NI, Tolstikov GA, Savinova OV, Boreko EI, Dolgushin FM. Betulonic amides modified at cycle A by amino acids: synthesis and inhibition of Flu A virus reproduction. Russ J Bioorg Chem. 2009;35:129-33. https://doi.org/10.1134/ s1068162009010154

24. Kazakova OB, Giniyatullina GV, Yamansarov EYU, Tolstikov GA. Betulin and ursolic acid synthetic derivatives as inhibitors of Papilloma virus. Bioorg Med Chem Lett. 2010;20:4088-90. https://doi.org/10.1016/j.bmcl.2010.05.083

25. Song G, Shen X, Li S, Li Y, Liu Y, Zheng Y, et al. Structureactivity relationships of 3-O-beta-chacotriosyl ursolic acid derivatives as novel $\mathrm{H} 5 \mathrm{~N} 1$ entry inhibitors. Eur J Med Chem. 2015;93:431-42. https://doi.org/10.1016/j.ejmech.2015.02.029

26. Boreko EI, Pavlova NI, Savinova OV, Nikolaeva SN, Flekhter $\mathrm{OB}$, Phyzhova NS, et al. Inhibition of virus reproduction and proteinase activity by lupane and some other terpenes. J Biomed Sc. 2002;3:86-90.

27. Flekhter OB, Ashavina OY, Smirnova IE, Baltina LA, Galin FZ, Kabal'nova NN, et al. Selective oxidation of triterpene alcohols by sodium hypochlorite. Chem Nat Comp. 2004;40:141-3. https:// doi.org/10.1023/B:CONC.0000033930.76751.b7

28. Huang ZJ, Zhang YH, Zhao L, Jing YW, Lai YS, Zhang LY, et al. Synthesis and anti-human hepatocellular carcinoma activity of new nitric oxide-releasing glycosyl derivatives of oleanolic acid. Org Biomol Chem. 2010;8:632-9. https://doi.org/10.1039/ B918846K

29. Platonov VG, Zorina AD, Gordon MA, Chizhov NP, Balykina LV, Mikhailov YuD, et al. Khim Farm Zh. 1995;29:42-46.

30. Zorina AD, Kaledina AS, Motsepuro IA, Anokhina VV, Marchenko SA, Selivanov SI, et al. Synthesis and anti-influenza activity of 2-Cyanoethoxy and 2-(1H-tetrazol-5-yl)ethoxy derivatives of Dammarane-type triterpenoids. Rus J Org Chem. 2017;53:1710-6. https://doi.org/10.1134/S1070428017110185

31. Medvedeva NI, Kazakova OB, Lopatina TV, Smirnova IE, Giniyatullina GV, Baikova IP, Kataev VE. Synthesis and antimycobacterial activity of triterpenic A-ring azepanes. Eur J Med Chem. 2018;143:464-72. https://doi.org/10.1016/j.ejmech.2017. 11.035

32. Kazakova OB, Lopatina TV, Baikova IP, Zileeva ZR, Vakhitova YV, Suponitsky KYU. Synthesis, evaluation of cytotoxicity, and antimicrobial activity of A-azepano- and A-seco-3-amino-C28aminolupanes. Med Chem Res. 2020;29:1507-19. https://doi.org/ 10.1007/s00044-020-02577-6
33. Kazakova OB, Medvedeva NI, Smirnova IE, Lopatina TV, Veselovsky AV. The introduction of hydrazone, hydrazide, or azepane moieties to the triterpenoid core enhances an activity against M. tuberculosis. Med Chem. 2020;16:1-12. https://doi. org/10.2174/1573406416666200115161700

34. Smirnova IE, Kazakova OB. Structure-anti-influenza type A activity relationship among a series of nitrogen lupane triterpenoids. Nat Prod Comm. 2018;13:1267-70. 10.1177\%2F1934578X1801301008

35. Tolmacheva IA, Grishko VV, Boreko EI, Savinova OV, Pavlova NI. Synthesis and antiviral activity of 2,3-seco-derivatives of betulonic acid. Chem Nat Compd. 2009;45:673-6. https://doi.org/ 10.1007/s10600-009-9436-5

36. Grishko VV, Galaiko NV, Tolmacheva IA, Kucherov II, Eremin VF.Boreko EI, et al. Functionalization, cyclization and antiviral activity of A-secotriterpenoids. Eur J Med Chem. 2014;83:601-8. https://doi.org/10.1016/j.ejmech.2013.12.058

37. Tolmacheva IA, Igosheva EV, Vikharev YB, Grishko VV, Savinova OV, Boreko EI, et al. Synthesis and biological activity of mono- and diamides of 2,3-secotriterpene acids. Russ J Bioorg Chem. 2013;39:186-93. https://doi.org/10.1134/S1068162013020143

38. Tolmacheva IA, Igosheva EV, Savinova OV, Boreko EI, Grishko VV. Synthesis and antiviral activity of C-3(C-28)-substituted 2,3seco-triterpenoids. Chem Nat Compd. 2014;49:1050-8. https:// doi.org/10.1007/s10600-014-0821-3

39. Zorina AD, Mikhailov YuD, Balykina LV, Smirnov II, Platonov VG, Gordon MA, et al. Synthesis of secoacids of the damarrane series. Pharm Chem J. 1997;31:330-2. https://doi.org/10.1007/BF02464128

40. Kazakova OB, Tret'yakova EV, Baev D. Evaluation of Aazepano-triterpenoids and related derivatives as antimicrobial and antiviral agents. J Antibiot. 2021;74:559-73. https://doi.org/10. 1038/s41429-021-00448-9

41. Antimonova AN, Uzenkova NV, Petrenko NI, Shakirov MM, Shul'ts EE, Tolstikov GA. Synthesis of betulonic acid amides. Chem Nat Comp. 2008;44:327-33. https://doi.org/10.1007/ s10600-008-9054-7

42. Yingqian L, Weiguo L, Junxiang Z, Chunhua L, Cheng C, Juncai L. Application of oleanolic acid and its derivatives for control of rice planthopper from faming Zhuanli Shenqing. Patent $\mathrm{CN}$ 108552175, 2018.

43. Do Thi Thu H, Tran Thi Thu T, Tran Thi H, Nguyen Thanh T, Nguyen Quyet T, Smirnova IE, et al. Synthesis and citotoxicity of derivatives of dipterocarpol, a metabolite of Dipterocarpus alatus. Chem Nat Compd. 2013;49:58-65. https://doi.org/10.1007/ s10600-013-0505-4

44. Saveleva OM, Bychkov KE. Formulation for activating telomerase and method for use. Patent RU 2593586 C1, 2018.

45. Ren Q, Yang G, Guo M, Guo J, Li Y, Lu J, et al. Design, synthesis, and discovery of ocotillol-type amide derivatives as orally available modulators of P-glycoprotein-mediated multidrug. Eur J Med Chem. 2019;161:118-30. https://doi.org/10.1016/j. ejmech.2018.10.038

46. Wrzeciono U, Mikolajewska A. Triterpene nitrogenous derivatives. VI. 3- and 28 $\beta$-Aminolupane derivatives. III Roczniki Chem. 1972;46:1285-93.

47. Wrzeciono U, Turowska W, Gorczynska L. Nitrogen derivatives of triterpenes. VII. Products of the reduction of oleanonic acid oxime and its methyl ester. Roczniki Chem. 1973;47:955-62.

48. Giniyatullina GV, Flekhter OB, Baikova IP, Starikova ZA, Tolstikov GA. Effective synthesis of methyl 3 $\beta$-amino-3deoxybetulinate. Chem Nat Comp. 2008;44:603-5. https://doi. org/10.1007/s10600-008-9138-4

49. Lopatina TV, Medvedeva NI, Baikova IP, Iskhakov AS, Kazakova OB. Synthesis and cytotoxicity of $O$ - and $N$-acyl derivatives of azepanobetulin. Russ J Bioorg Chem. 2019;45:292-301. https://doi.org/10.1134/S106816201904006X 
50. Kazakova O, Smirnova I, Lopatina T, Giniyatullina G, Petrova A, Khusnutdinova E, et al. Synthesis and cholinesterase inhibiting potential of A-ring azepano- and 3-amino-3,4-seco-triterpenoids. Bioorg Chem. 2020. https://doi.org/10.1016/j.bioorg.2020.104001

51. Medvedeva NI, Kazakova OB, Lopatina TV, Smirnova IE, Giniyatullina GV, Baikova IP, Kataev VE. Synthesis and antimycobacterial activity of triterpenic A-ring azepanes. Eur J Med Chem. 2018;143:464-72. https://doi.org/10.1016/j.ejmech.2017.11.035
52. Kazakova OB, Brunel JM, Khusnutdinova EF, Negrel S, Giniyatullina GV, Lopatina TV, et al. A-ring modified triterpenoids and their spermidine-aldimines with strong antibacterial activity. Mol-bank. 2019;M1078. https://doi.org/10.3390/M1078

53. Kazakova OB, Giniyatullina GV, Tolstikov GA. Synthesis of Aseco-methylenamino- and substituted amidoximotriterpenoids. Russ J Bioorg Chem. 2011;37:619-25. https://doi.org/10.1134/ s1068162011050086 